\title{
Genetic Variability in Yield and Its Attributes of some Peanut (Arachis hypogaea L.) Genotypes under Different Water Regimes
}

\author{
Ali A. A. ${ }^{1}$, Ebtsam M. Abo El-Hassan ${ }^{1}$, E. M. El-Areny ${ }^{2}$ and M. A. Emam ${ }^{1}$ \\ ${ }^{1}$ Agronomy Dep. Fac. of Agric., Suez Canal University, 41522 Ismailia, Egypt \\ ${ }^{2}$ Agricultural Researches Station, Ismailia Governorate
}

Received: $7 / 12 / 2020$

\begin{abstract}
The objective of this study was to investigate the response of advanced peanut breeding lines to water stress to identify the tolerant genotypes and the drought tolerance related traits besides to assess the genetic variability between genotypes under drought stress. Thus, two field experiments were conducted during the two successive seasons 2018 and 2019, in the Agricultural Research Station, Ismailia Governorate. Assessment of ten genotypes and three water regimes was done in a randomized complete block design with three replications. The water regimes were a full irrigation $100 \% \mathrm{w}$ as a control, $75 \% \mathrm{w}$ and $50 \% \mathrm{w}$ stress irrigation. The results indicated existence of moderate genetic variability accompanied with high heritability and high GAM among the studied traits; days to maturity, shelling \%, pod yield/plant, seed yield/plant and oil content under stress conditions. Also, the results indicated significant differences among the tested genotypes for all the investigated traits. Yield and its attributes of all genotypes varied under water stress and significant responses were observed. The genotypes No. 5, 6 and 3, showed the highest values for most of the yield and its attributes under the different water regimes. So, these genotypes are considered promising in peanut improvement program to produce drought tolerant varieties of peanut characterized with high yielding ability.
\end{abstract}

Keywords: Drought, GCV, PCV heritability, seed yield, peanut and yield components

\section{INTRODUCTION}

Peanut (Arachis hypogea L.) is an annual highly self-pollinated oil-seed legume cash crop, with limited genetic base. It is mainly grown in temperate and tropical regions of the world as rain fed crop, about $95 \%$ of its cultivated area is in the semi-arid tropics, it's grown in over 100 countries, covering more than 28 million hectares with global production of about $46 \mathrm{M}$ tons and an average yield of about 1.655 ton/ha. Asia (58.3\%) and Africa (31.6\%) accounted for about $90 \%$ of the world's production. China (14.1 M tons), India (7.2 $\mathrm{M}$ tons) and Nigeria (2.8 $\mathrm{M}$ tons) being the top three largest producing countries (FAO, 2020).

Peanut is cultivated almost all over Egypt covering 65000 ha with production 187094.92 tons (FAO, 2020). Peanut is used for edible oil, food and animal feed. Also, the green leaves are used as hay for livestock (Abdalla et al., 2009). Its seeds are valued for its oil and protein contents where, it contains $40-55 \%$ oil and 22-32\% digestible protein (FAO, 2008).

Genotypic variation in peanut yield traits was reported by several investigators (Pimratch et al., 2010; Pereiral et al., 2015). The existence of genetic variability for yield traits indicates that these traits of peanut could be improved by conventional breeding programs. Numerous studies on peanut have been carried out, yet, there is limited information about its genetics, breeding and production (Nassar et al., 2018).

According to the high complexity of the relevant genetic background for peanut, particularly the quantitative characters are controlled by several genes spread through the chromosomal sets of peanuts (Fonceka et al., 2012), selection of varieties for high yield under drought environment is the major challenge for improving peanut productivity. However, pod yield per plant, number of mature pods per plant, and 100- seed weight are important characters for pod yield under drought stress (Aminifar et al., 2013).

Developing drought tolerant peanut genotypes is a successful approach adopted to alleviate drought stress problems and to ensure sufficient production in droughtthreatened areas (De Lima Pereira et al., 2016; Pereira et al., 2012; Songsri et al., 2008). Besides anchoring the plant within the ground, the root system is the major organ to improve crop adaptation to water stress (Gowda et al., 2012).

\section{MATERIALS AND METHODS}

Ten peanut genotypes, eight of them selected from three improved population (El-Areny, 2015) and two check cultivars (Giza 6 and Gregory) were used for the present study.

\section{Experimental Materials:}

The material of the present study consisted of 10 peanut genotypes; the informations of genotypes are provided in Table (1).

\section{Field experiment:}

Two field experiments were conducted at Ismailia Agricultural Research Station during 2018 and 2019 summer seasons with normal irrigation and stress condition at 45 days after sowing (DAS) to evaluate the tested genotypes of peanut for their tolerance to drought condition based on the morphological and physiological parameters. The drought stress levels were, Wellwatered $(100 \% \mathrm{WW})$ as recommended irrigation, $75 \%$ $(75 \% \mathrm{~W})$ and $50 \%$ of recommended irrigation $(50 \% \mathrm{~W})$ in the region.

\section{Experimental Design:}

The experiment was laid out in a Randomized Complete Block Design with three replications.Each replication includes three water regimes as a main plot. 
Each main plot includes 10 genotypes as a sub-plot. The experiment was sown on 12 May 2018 and 2019. Each genotype was sown in three rows plot, $3 \mathrm{~m}$ long and 60 $\mathrm{cm}$ apart with 10-20 $\mathrm{cm}$ between hills according to the genotype growth habit and one plant was kept per hill.

\section{Recorded traits:}

Five guarded plants were selected randomly as a sample for each genotype, and the following parameters were recorded at harvest; Days to maturity, Pod yield per plant (g), Seed yield per plant (g), Shelling percentage and Oil content.

\section{Statistical analysis:}

Data of experiments were analyzed according to the procedure of Randomized complete block designsplit plot (Steel and Torrie, 1984). Software program, SPSS was used to perform the analysis and the means were compared using LSD. The genotypic and phenotypic coefficients of variation were undertaken according to Burton and Devane (1953). Broad sense heritability values were estimated according to Hanson et al. (1956). The genetic advance as percent of population mean was also estimated following the procedure of Johnson et al. (1955).

Table (1): The number, sources, pedigree and growth habit of the studied genotypes

\begin{tabular}{ccccc}
\hline Genotype No. & Genotype source & Pedigree & Origin & Growth habit \\
\hline $\mathbf{1}$ & Population I & $293 \times 525$ & U.S.A x China & Erect. \\
$\mathbf{3}$ & & & China x & Erect x Semi- \\
$\mathbf{4}$ & Population II & $525 \times 623$ (Gregory) & U.S. A & Spreading \\
$\mathbf{5}$ & & & Semi spreading x \\
$\mathbf{6}$ & Population III & R92 x 623(Gregory) & U.S. A & Spreading \\
$\mathbf{7}$ & Giza 6 & Not available & Local & U.S. A
\end{tabular}

\section{RESULTS AND DISCUSSION}

\section{Analysis of Variance and Mean Performance:}

Analysis of variance of all the studied characters of genotypes under different water regimes during 2018 and 2019 seasons is illustrated in Table (2). The results indicated that there were highly significant differences among the evaluated genotypes for all studies traits during both seasons.

Regarding to water regimes, all traits showed highly significant differences during 2018 and 2019 seasons. All the interactions between genotypes and water regimes were significant or highly significant for all traits under study in both seasons of study.

The abovementioned results are revealing that there was genotypic variation among the genotypes in both seasons and their performance differed in the different water regimes for all studies traits. Genotypic variation in peanut yield traits was reported by several investigators, e.g. (Pimratch et al., 2010; Pereiral et al., 2015). The existence of genetic variability in peanut yield traits indicates that these traits could be improved by conventional breeding programs. Stress caused by water deficit affects growth and development of peanut plants. However, the response of plants varies with the degree of stress and crop growth stage.

These results agreed with that of many researchers, drought stress during different growth stages is one of the limiting factors for the pod yield in peanut (Shinde et al., 2010; Hamidou et al., 2012). Also, Maria Balota (2012) reported that, emergence, flowering, pegging, and pod filling are considered as the critical growth stages of peanut under drought stress condition.

\section{Agronomic traits:}

Regarding days to maturity, highly significant differences were exhibited between genotypes, water regimes in 2018 and 2019 seasons. Also, highly significant interaction between genotypes and the water regimes was obtained. Water stress had a significant effect on days to maturity; however, it delayed days to maturity by 16.47 and 12.64 days; from 133.4 and 125.33 (control treatment) to 149.87 and 137.97 under $(50 \% \mathrm{w})$ in both seasons, respectively.

The earliest plants were found in genotype No. 3 and No. 2 under control and No. 9 under $75 \% \mathrm{~W}$ regime, and followed by genotype No. 1 under both control treatment and $75 \% \mathrm{w}$ regime, while under $50 \% \mathrm{~W}$ level, genotypes No. 2 and No. 3 were the earliest in 2019 Table (3). Same trend of results was obtained by Savita (2014) and Thombare (2017), supporting the present one, showing a significant increase for peanut days to maturity under water deficit conditions.

\section{Yield and yield components:}

Concerning the results, shelling \% indicated in Table (4) showed highly significant effects among all genotypes in 2018 and 2019 seasons. In 2018 season, genotype No.6 gave the highest average of shelling percentage $(77.87 \%)$, followed by genotype No.8 $(73.03 \%)$, while in 2019 , genotype No.3 gave the highest shelling \% (70.42), followed by genotype No.7 which recorded $69.98 \%$. The water stress caused highly significant differences in this trait as shown in Table (4), where it recorded 81.16 and $80.65 \%$ under control versus reduction to $69.27 \%$ and $64.59 \%$ for $75 \% \mathrm{~W}$ then to 56.83 and $52.11 \%$ under $50 \%$ water regimes, in both seasons, respectively. 
Table (2): Mean squares of the studied traits recorded for peanut genotypes under drought regimes during 2018 and 2019 seasons

\begin{tabular}{|c|c|c|c|c|c|c|c|c|c|c|c|}
\hline \multirow{2}{*}{ S.O. V } & \multirow{2}{*}{ D.F. } & \multicolumn{2}{|c|}{ Days to maturity } & \multicolumn{2}{|c|}{ Shelling \% } & \multicolumn{2}{|c|}{ Pod yield/plant (g) } & \multicolumn{2}{|c|}{ Seed yield/plant (g) } & \multicolumn{2}{|c|}{ Oil content } \\
\hline & & 2018 & 2019 & 2018 & 2019 & 2018 & 2019 & 2018 & 2019 & 2018 & 2019 \\
\hline Blocks & 2 & 7.078 & 4.478 & .040 & 49.586 & .357 & .199 & 2.640 & 11.072 & 5.011 & 5.787 \\
\hline Water & 2 & $2559.878 * *$ & $3323.744 * *$ & $4438.700 * *$ & $6141.236^{* *}$ & $5778.768^{* *}$ & $5002.803 * *$ & $6848.236^{* *}$ & $7803.981 * *$ & $3390.121 * *$ & $2958.688^{* *}$ \\
\hline $\begin{array}{l}\text { Main Plot } \\
\text { Error }\end{array}$ & 4 & 2.444 & 1.011 & 41.377 & 8.794 & .159 & .055 & 10.785 & 1.958 & 1.111 & 4.016 \\
\hline Genotypes & 9 & $2243.468^{* *}$ & $1671.641^{* *}$ & $202.583 * *$ & $303.336^{* *}$ & $820.623 * *$ & $324.042 * *$ & $521.138^{* *}$ & $302.389 * *$ & $24.276 * *$ & $19.576^{* *}$ \\
\hline$W^{*} \mathbf{G}$ & 18 & $539.372 * *$ & $198.559 * *$ & $208.470 * *$ & $49.986^{* *}$ & $154.974 * *$ & $121.482 * *$ & $74.586^{* *}$ & $55.256^{* *}$ & $14.499 * *$ & $17.266^{* *}$ \\
\hline Error (b) & 54 & .989 & 1.142 & 23.010 & 24.674 & .078 & .114 & 5.986 & 6.289 & 4.429 & 4.282 \\
\hline Total & 89 & & $* *$ signif & ant at $1 \%$ les & & & & & & & \\
\hline
\end{tabular}

Table (3): Mean performance of days to maturity for peanut genotypes under different water regimes during 2018 and 2019 seasons

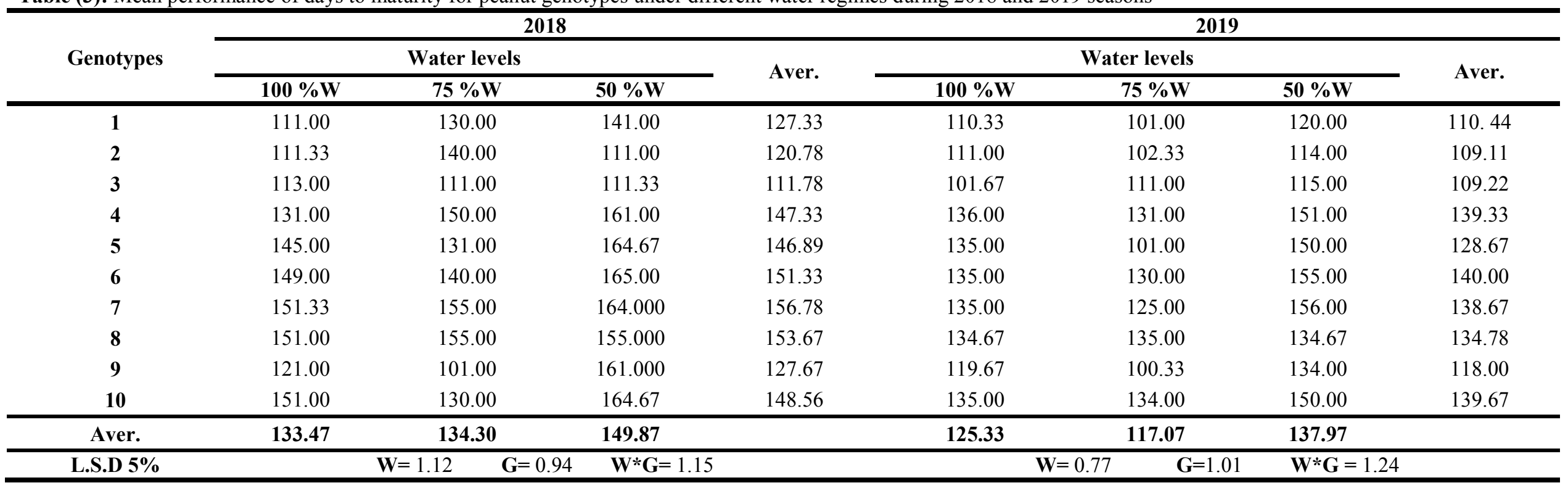


Table (4): Mean performance of shelling \% for peanut genotypes under different water regimes during 2018 and 2019 seasons

\begin{tabular}{|c|c|c|c|c|c|c|c|c|}
\hline \multirow{3}{*}{ Genotypes } & \multicolumn{4}{|c|}{2018} & \multicolumn{4}{|c|}{2019} \\
\hline & \multicolumn{3}{|c|}{ Water levels } & \multirow{2}{*}{ Aver. } & \multicolumn{3}{|c|}{ Water levels } & \multirow{2}{*}{ Aver. } \\
\hline & $100 \% W$ & $75 \% W$ & $50 \% W$ & & $100 \% W$ & $75 \% W$ & $50 \% W$ & \\
\hline 1 & 81.41 & 69.70 & 65.21 & 72.11 & 78.66 & 72.22 & 56.96 & 69.28 \\
\hline 2 & 82.01 & 55.99 & 52.85 & 63.61 & 77.45 & 64.50 & 54.38 & 65.44 \\
\hline 3 & 72.45 & 63.15 & 60.09 & 65.23 & 84.62 & 70.62 & 56.01 & 70.42 \\
\hline 4 & 79.98 & 60.29 & 46.42 & 62.23 & 80.15 & 60.00 & 39.54 & 59.90 \\
\hline 5 & 76.41 & 75.97 & 59.51 & 70.63 & 84.78 & 63.16 & 57.69 & 68.54 \\
\hline 6 & 83.25 & 77.53 & 72.82 & 77.87 & 84.11 & 58.52 & 52.49 & 65.04 \\
\hline 7 & 85.02 & 79.72 & 35.53 & 66.76 & 86.50 & 66.36 & 57.08 & 69.98 \\
\hline 8 & 86.57 & 72.49 & 60.04 & 73.03 & 79.02 & 74.69 & 55.13 & 69.62 \\
\hline 9 & 91.60 & 65.97 & 52.84 & 70.14 & 68.33 & 49.88 & 37.70 & 51.97 \\
\hline 10 & 72.86 & 71.94 & 63.00 & 69.27 & 82.90 & 65.97 & 54.16 & 67.68 \\
\hline Aver. & 81.16 & 69.27 & 56.83 & & 80.65 & 64.59 & 52.11 & \\
\hline L.S.D 5\% & $\mathbf{W}=$ & $\mathbf{G}=$ & $W * C$ & & W & $\mathbf{G}=4$. & $\mathbf{W} * \mathbf{G}=$ & \\
\hline
\end{tabular}

The results of shelling \% also, showed significant differences in the interaction between water regimes and the genotypes in both seasons affected differences this trait. Where, the highest shelling \% under control regime was recorded by genotype No.9 (91.6) followed by No.8 (86.57) in the $1^{\text {st }}$ season, while in the $2^{\text {nd }}$ season, genotypes No.7 (86.5) followed by No.5 (84.78) surpassed other genotypes in this trait. On the other hand, the studied genotypes differently responded to the drought stress, however, genotypes No.7 (79.72) and No.6 (77.53) in the $1^{\text {st }}$ season, genotypes No.8 (74.69) and No.1 (72.21) surpassed other genotypes in the $2^{\text {nd }}$ season under the treatment of $75 \% \mathrm{~W}$. Also, genotype No.6 (72.82) in the $1^{\text {st }}$ season; No.5 (57.69) and No.7 (57.08) in the $2^{\text {nd }}$ season recorded higher shelling \% than the other genotypes under the severe drought stress $50 \% \mathrm{~W}$. Shoba et al. (2012) observed that shelling\% could be considered as the outstanding character affecting seed yield in peanut. These results were in agreement with those obtained by Thakur et al. (2013) and Thombare (2017).

The results of pod yield/plant showed in Table (5) indicated highly significant differences among all the genotypes in both 2018 and 2019 seasons. In 2018 genotype No.5 recorded the heaviest pod yield/plant $(65.56 \mathrm{~g})$, followed by genotypes No.6, No.4 and No.3. In 2019, genotype No.2 gave the highest pod weight/plant $(60.27 \mathrm{~g})$, followed by the genotypes No.7 and No.5. On the other hand, the genotypes No.8 and No.10 in the $1^{\text {st }}$ season; No.6 and No.8 in the $2^{\text {nd }}$ season recorded the lowest pod yield/plant.

The water stress caused highly significant differences in pod yield/plant as indicated in Table (5). In 2018 , the average pod yield/plant under control was
$61.27 \mathrm{~g}$ and reduced to $49.23 \mathrm{~g}$ and $33.59 \mathrm{~g}$ affected by the $75 \% \mathrm{~W}$ and $50 \%$ water regimes, respectively. Also, the same trend was observed for 2019 season where it gave $65.53 \mathrm{~g}, 52.48 \mathrm{~g}$ and $39.70 \mathrm{~g}$ for the control, $75 \%$ and $50 \%$ water regimes, respectively. The negative effects on pod yield/plant due to water deficit appeared in recoded reduction rate, which was $19.6 \%$ and $45.2 \%$ in 2018 season versus $19.9 \%$ and $39.4 \%$ in 2019 season for $75 \%$ and $50 \%$ water regimes, respectively. The results of pod yield/plant in Table (5) showed significant interaction between the genotypes and water regimes in both seasons. Where in 2018, genotype No. 5 had the highest pod yield/plant under the three water regimes, recording $84.53 \mathrm{~g}, 71.27 \mathrm{~g}$ and 40.87 under control; 75\% W and $50 \% \mathrm{~W}$, respectively. In 2019 under control treatment the genotype No. 10 recorded the highest pod yield/plant (73.60 g), while under 75\% and $50 \% \mathrm{~W}$ treatments the genotypes No.2 and genotype No.7 recorded the highest values (65.53 and $47.53 \mathrm{~g})$, respectively, as compared to the other genotypes.

On the other hand, the genotype No. 10 gave the lowest pod yield/plant (33.27 and 19.87g) in 2018, while the genotype No.8 yielded the lowest pod weight/plant (40.07 and 30.87g) in 2019 under both $75 \% \mathrm{~W}$ and $50 \% \mathrm{~W}$ stress treatments, respectively. These results were in agreement with those obtained by Reshma (2014), Luis et al. (2016), Carvalho et al. (2017), Zurweller et al. (2018).

Genotypic variance may have a high impact on crop yield and its components, as these traits are controlled by polygenes and strongly influenced by the environment (Cattivelli et al., 2008). 
Table (5): Mean performance of pod yield plant $^{-1}$ for peanut genotypes under different water regimes during 2018,2019 seasons

\begin{tabular}{|c|c|c|c|c|c|c|c|c|}
\hline \multirow{3}{*}{ Genotypes } & \multicolumn{4}{|c|}{2018} & \multicolumn{4}{|c|}{2019} \\
\hline & \multicolumn{3}{|c|}{ water levels } & \multirow{2}{*}{ Aver. } & \multicolumn{3}{|c|}{ water levels } & \multirow{2}{*}{ Aver. } \\
\hline & $100 \% W$ & $75 \% W$ & $50 \% W$ & & $100 \% W$ & $75 \% W$ & $50 \% W$ & \\
\hline 1 & 81.41 & 69.70 & 65.21 & 72.11 & 78.66 & 72.22 & 56.96 & 69.28 \\
\hline 2 & 82.01 & 55.99 & 52.85 & 63.61 & 77.45 & 64.50 & 54.38 & 65.44 \\
\hline 3 & 72.45 & 63.15 & 60.09 & 65.23 & 84.62 & 70.62 & 56.01 & 70.42 \\
\hline 4 & 79.98 & 60.29 & 46.42 & 62.23 & 80.15 & 60.00 & 39.54 & 59.90 \\
\hline 5 & 76.41 & 75.97 & 59.51 & 70.63 & 84.78 & 63.16 & 57.69 & 68.54 \\
\hline 6 & 83.25 & 77.53 & 72.82 & 77.87 & 84.11 & 58.52 & 52.49 & 65.04 \\
\hline 7 & 85.02 & 79.72 & 35.53 & 66.76 & 86.50 & 66.36 & 57.08 & 69.98 \\
\hline 8 & 86.57 & 72.49 & 60.04 & 73.03 & 79.02 & 74.69 & 55.13 & 69.62 \\
\hline 9 & 91.60 & 65.97 & 52.84 & 70.14 & 68.33 & 49.88 & 37.70 & 51.97 \\
\hline 10 & 72.86 & 71.94 & 63.00 & 69.27 & 82.90 & 65.97 & 54.16 & 67.68 \\
\hline Aver. & 81.16 & 69.27 & 56.83 & & 80.65 & 64.59 & 52.11 & \\
\hline L.S.D 5\% & $\mathbf{W}=4$ & $\mathbf{G}=$ & $\mathrm{W} * \mathrm{C}$ & .55 & $\mathbf{W}=$ & $\mathbf{G}=4$ & $\mathbf{W} * \mathbf{G}=$ & \\
\hline
\end{tabular}

The results of seed yield/plant (g) illustrated in Table (6) indicated highly significant differences among all the genotypes in both 2018 and 2019 seasons. In 2018 genotype No.6 recorded the heaviest average weight of seed yield/plant $(47.96 \mathrm{~g})$, followed by genotype No.5 (47.68g). In 2019 genotype No.7 gave the highest seed yield/plant $(41.84 \mathrm{~g})$, followed by genotypes No.5, No.2 and No.3 (40.87, 40.47 and 40.22), respectively.

The water stress caused highly significant differences as showed in Table (6). In 2018 season, the recorded average seed yield/plant was $49.37 \mathrm{~g}$ under control, however reduced to $34.11 \mathrm{~g}$ and $19.15 \mathrm{~g}$ under the $75 \%$ and $50 \%$ water regimes, respectively. Also, the same trend was observed for the 2019 season where it was $(52.93 \mathrm{~g}),(33.77 \mathrm{~g})$ and $(20.87 \mathrm{~g})$ for the control, $75 \%$ and $50 \%$ water regimes respectively. The negative effects of water stress appeared in the reduction rate, which recorded decrease of $31 \%$ and $36 \%$ for $75 \%$ and $61 \%$ and $61 \%$ for $50 \%$ water regime in both seasons, respectively.

The results of seed yield/plant (g) illustrated in Table (6) showed significant interaction between the genotypes and water regimes in 2018 season, the highest seed yield/plant weight under control regime was recorded by genotype No.5 (64.59g) and No.6 (62.49). Also, the same genotypes No.5 and No.6 surpassed all other genotypes under $75 \%$ and $50 \%$ regimes. In 2019 the genotype No. 5 had the heaviest seed weight/plant $(61.67 \mathrm{~g})$ under control, while the genotype No. 2 (42.27) followed by No. 7 (38.13) that had the heaviest weight under the $75 \%$ reduced to (27.13) under 50\% water regime.

Ratnakumar and Vadez (2011) stated that the seed weight significantly reduced under drought stress in peanut genotypes and the more tolerant genotypes were able to maintain better yield. Our results were in harmony with the findings of Jibrin and Habu (2016) and Shrief et al. (2020).

\section{Quality parameters:}

The results of oil content, Table (7) indicated highly significant differences among all the genotypes in both 2018 and 2019 seasons, where the genotypes No.1, 2 and 3 recorded the highest oilcontent. The water stress caused highly significant differences as indicated in Table (7). In 2018 season, the recorded average oil content of (47.26) under control was reduced to (35.27) and (25.18) for the 75 and 50\% water regimes, respectively. Also, the same trend was observed for the 2019 season where it was (44.19), (33.87) and $(24.33 \%)$ for the control, 75 and $50 \%$ water regimes, respectively.

Significant interaction between the genotypes and water regimes for this trait were detected. In 2018 season, the highest oil content under control regime was given by genotype No. 6 followed by No. 3 recording (48.33 and $48.00 \%$ ), respectively, while genotype No. 2 followed by No. $3(37.03,36.3 \%)$ and genotype No.1 followed by No. 2 (35.07, 27.5\%) registered the highest oil content under 75 and 50\% regimes, respectively, and genotype No. 7 recorded the lowest values $(33.4,23.3)$ under 75 and $50 \% \mathrm{~W}$ treatments, respectively. In 2019, the genotype No. 3 had the highest value (46.8) under control, the genotypes No. 2 and No. 3 had the highest values $(35.6,34.9 \%)$ under the $75 \% \mathrm{~W}$ treatment, while under $50 \% \mathrm{~W}$ the genotype No.1 had the highest content of oil (33.33).

Our results are in harmony with the findings of Vaghasia et al. (2010), Paknejad et al. (2012), Menpadi et al. (2015) and Thombare (2017). 
Table (6): Mean performance of seed yield plant $^{-1}$ for peanut genotypes under different regimes during 2018 and 2019 seasons

\begin{tabular}{|c|c|c|c|c|c|c|c|c|}
\hline \multirow{3}{*}{ Genotypes } & \multicolumn{4}{|c|}{2018} & \multicolumn{4}{|c|}{2019} \\
\hline & \multicolumn{3}{|c|}{ water levels } & \multirow{2}{*}{ Aver. } & \multicolumn{3}{|c|}{ water levels } & \multirow{2}{*}{ Aver. } \\
\hline & $100 \% W$ & $75 \% W$ & $50 \% W$ & & $100 \% W$ & $75 \% W$ & $50 \% W$ & \\
\hline 1 & 45.59 & 28.35 & 23.43 & 32.46 & 57.27 & 32.93 & 23.73 & 37.98 \\
\hline 2 & 43.74 & 25.27 & 17.56 & 28.85 & 55.20 & 42.27 & 23.93 & 40.47 \\
\hline 3 & 46.85 & 38.27 & 19.63 & 34.92 & 56.87 & 38.00 & 25.80 & 40.22 \\
\hline 4 & 52.10 & 33.95 & 17.88 & 34.65 & 49.00 & 33.00 & 12.20 & 31.40 \\
\hline 5 & 64.59 & 54.14 & 24.32 & 47.68 & 61.67 & 34.93 & 26.00 & 40.87 \\
\hline 6 & 62.49 & 52.36 & 29.03 & 47.96 & 36.33 & 24.73 & 18.65 & 26.57 \\
\hline 7 & 50.67 & 26.94 & 11.23 & 29.61 & 60.27 & 38.13 & 27.13 & 41.84 \\
\hline 8 & 35.90 & 29.09 & 20.29 & 28.43 & 53.00 & 29.93 & 19.40 & 34.11 \\
\hline 9 & 46.23 & 28.78 & 15.61 & 30.20 & 38.67 & 26.67 & 15.13 & 26.82 \\
\hline 10 & 45.51 & 23.92 & 12.52 & 27.32 & 61.00 & 37.13 & 16.73 & 38.29 \\
\hline Aver. & 49.37 & 34.11 & 19.15 & & 52.93 & 33.77 & 20.87 & \\
\hline L.S.D 5\% & $\mathbf{W}=2.35$ & $\mathbf{G}=2.31$ & $\mathbf{W} * \mathbf{G}=$ & & $\mathbf{W}=$ & $\mathbf{G}=2.37$ & $\mathbf{W}^{*} \mathbf{G}=$ & 90 \\
\hline
\end{tabular}

Table (7): Mean performance of oil content for peanut genotypes under different water regimes during 2018 and 2019

\begin{tabular}{|c|c|c|c|c|c|c|c|c|}
\hline \multirow{3}{*}{ Genotypes } & \multicolumn{4}{|c|}{2018} & \multicolumn{4}{|c|}{2019} \\
\hline & \multicolumn{3}{|c|}{ water levels } & \multirow{2}{*}{ Aver. } & \multicolumn{3}{|c|}{ water levels } & \multirow{2}{*}{ Aver. } \\
\hline & $100 \% W$ & $75 \% W$ & $50 \% W$ & & $100 \% W$ & $75 \% W$ & $50 \% W$ & \\
\hline 1 & 48.93 & 35.43 & 35.07 & 38.68 & 44.33 & 34.03 & 33.33 & 37.23 \\
\hline 2 & 48.27 & 37.03 & 27.50 & 36.60 & 44.07 & 35.63 & 25.77 & 35.16 \\
\hline 3 & 50.00 & 36.30 & 25.67 & 36.52 & 46.80 & 34.90 & 23.57 & 35.09 \\
\hline 4 & 43.03 & 35.17 & 24.43 & 33.54 & 39.83 & 33.77 & 22.70 & 32.10 \\
\hline 5 & 46.37 & 34.80 & 27.57 & 35.36 & 42.50 & 33.40 & 25.83 & 33.91 \\
\hline 6 & 48.33 & 34.60 & 22.33 & 34.42 & 45.13 & 33.20 & 20.60 & 32.98 \\
\hline 7 & 47.37 & 33.40 & 23.33 & 33.60 & 46.20 & 32.00 & 21.63 & 32.17 \\
\hline 8 & 47.40 & 34.77 & 24.00 & 35.17 & 45.20 & 33.70 & 23.27 & 33.72 \\
\hline 9 & 47.57 & 34.77 & 24.00 & 34.33 & 44.03 & 33.37 & 22.30 & 32.90 \\
\hline 10 & 45.30 & 36.07 & 26.07 & 35.14 & 42.10 & 34.67 & 24.30 & 33.69 \\
\hline Aver. & 47.26 & 35.27 & 26.06 & & 44.19 & 33.87 & 24.30 & \\
\hline L.S.D 5\% & \multicolumn{2}{|c|}{$\mathbf{W}=0.76$} & \multicolumn{2}{|c|}{$\mathbf{W} * \mathbf{G}=2.44$} & $\mathbf{W}=1$ & $\mathbf{G}=1$ & \multicolumn{2}{|c|}{$\mathbf{W} * \mathbf{G}=2.40$} \\
\hline
\end{tabular}


Variability of peanut genotypes under different water regimes:

Genetic advance has been used to estimate the genetic gain for the genotypes under selection. Three main factors define (heritability, genetic variability and selection intensity) the genetic advance under selection. Consequently, due to high genetic variability or and heritability, a high genetic advance can be attributed. When a trait shows high genetic advance, selection will be rewarding for improvement of such trait.

The results of genotypic coefficient of variation (GCV), phenotypic coefficient of variation (PCV), heritability $\left(\mathrm{h}^{2}\right)$, expected genetic advance (GA) and expected geneticadvance percentage (GAM) over mean for various characters are presented in Table (8).

Among studied agronomical parameters under stress condition, days to maturity exhibited moderate genetic variability accompanied with high heritability and high GAM.
The results indicated that moderate to high genetic variability was recorded for each of pod yield/plant and seed yield/plant, also recorded high heritability and GAM, in the 2018 and 2019 seasons. While, Shelling \% exhibited low to moderate PCV and GCV and moderate to high heritability in both seasons, and the GAM was low to high in 2018 season and moderate to high in 2019 season. Oil content showed a low to moderate PCV and GCV, high heritability and low to moderate GAM. These findings were in same trend with those obtained by Roy et al. (2018); Shankar et al. (2019a, b) and Meghala (2019).

Generally, the existence of genetic variability for yield traits indicates that these traits of peanut could be improved by conventional breeding programs. Selection of varieties having high yield under drought environment is the major criterion forimproving peanut productivity (Nassar et al., 2018). However, pod yield per plant and 100-seed weight are important characters for pod yield under drought stress Aminifar et al. (2013), Jeyaramraja and Woldesenbet (2014).

Table (8): Variability parameters for different characters at two water regimes in 10 peanut genotypes in 2018 and 2019 seasons

\begin{tabular}{|c|c|c|c|c|c|c|c|c|c|}
\hline Characters & Season & Water regime & Mean & Range & GCV & PCV & h2 & GA & GAM \\
\hline \multirow{4}{*}{ Days to maturity. } & \multirow{2}{*}{2018} & (Control) & 133.47 & $111.0-151.3$ & 13.40 & 13.43 & 99.60 & 36.77 & 27.55 \\
\hline & & $50 \%$ & 149.87 & $111.0-165.0$ & 14.44 & 14.45 & 99.79 & 44.52 & 29.71 \\
\hline & \multirow{2}{*}{2019} & Control & 125.33 & $101.7-136.0$ & 10.62 & 10.65 & 99.40 & 27.33 & 21.81 \\
\hline & & $50 \%$ & 137.97 & $114.0-156.0$ & 12.14 & 12.16 & 99.67 & 34.44 & 24.96 \\
\hline \multirow{4}{*}{ Shelling\% } & \multirow{2}{*}{2018} & Control & 81.16 & $72.5-91.6$ & 6.08 & 9.57 & 40.44 & 6.47 & 7.97 \\
\hline & & $50 \%$ & 56.83 & $35.5-72.8$ & 14.82 & 17.32 & 73.22 & 14.84 & 26.12 \\
\hline & \multirow{2}{*}{2019} & Control & 80.65 & $68.3-86.5$ & 6.09 & 7.45 & 66.72 & 8.26 & 10.24 \\
\hline & & $50 \%$ & 52.11 & $37.7-52.9$ & 13.32 & 15.27 & 76.07 & 12.47 & 23.93 \\
\hline \multirow{4}{*}{ Pod yield/plant (g) } & \multirow{2}{*}{2018} & Control & 61.27 & $41.5-84.5$ & 20.07 & 20.08 & 99.95 & 25.33 & 41.34 \\
\hline & & $50 \%$ & 33.59 & $19.9-40.9$ & 18.08 & 18.09 & 99.89 & 12.50 & 37.22 \\
\hline & \multirow{2}{*}{2019} & Control & 65.53 & $43.2-73.6$ & 14.59 & 14.60 & 99.89 & 19.68 & 30.04 \\
\hline & & $50 \%$ & 39.70 & $30.9-47.5$ & 15.60 & 15.63 & 99.59 & 12.73 & 32.07 \\
\hline \multirow{4}{*}{ Seed yield/plant (g) } & \multirow{2}{*}{2018} & Control & 49.37 & $64.6-35.9$ & 14.39 & 15.94 & 81.49 & 15.21 & 26.76 \\
\hline & & $50 \%$ & 19.15 & $11.2-29.0$ & 15.33 & 17.32 & 78.28 & 5.35 & 27.93 \\
\hline & \multirow{2}{*}{2019} & Control & 52.927 & $36.3-61.6$ & 16.79 & 17.43 & 92.78 & 17.63 & 33.31 \\
\hline & & $50 \%$ & 20.78 & $12.2-27.1$ & 24.34 & 25.48 & 91.30 & 10.00 & 47.91 \\
\hline \multirow{4}{*}{ Oil content. } & \multirow{2}{*}{2018} & (Control) & 44.687 & $41.0-46.3$ & 3.98 & 4.55 & 76.7 & 3.40 & 7.19 \\
\hline & & $50 \%$ & 26.057 & $22.3-35.1$ & 12.99 & 15.13 & 73.73 & 5.99 & 22.98 \\
\hline & \multirow{2}{*}{2019} & Control & 43.487 & $39.8-46.8$ & 4.52 & 4.89 & 85.63 & 3.81 & 8.62 \\
\hline & & $50 \%$ & 24.33 & $20.6-33.3$ & 13.90 & 16.17 & 73.85 & 5.99 & 24.60 \\
\hline
\end{tabular}




\section{REFERENCES}

Abdalla, A. A., M. A. El-Howeity and A. H. Desoky (2009). Response of peanut crop cultivated in newly reclaimed soil to inoculation with plant growth- promoting rhizobacteria. Minufiya J. Agric. Res., 34: 2281-2304.

Aminifar, J., M. Mousavinik and A. Sirousmehr (2013). Grain yield improvement of peanut (Arachis hypogea L.) under drought stress conditions. Int. J. Agri. Crop Sci., 6(12): 819824.

Burton, G. N. and E. M. Devane (1953). Estimating heritability in tall fescue (Festuca arundianacea L.) from replicated clonal material. Agron. J., 45:478-481.

Carvalho, M. J., N. Vorasoot, N. Puppala, A. Muitia and S. Jogloy (2017). Effects of terminal drought on growth, yield and yield components in Valencia peanut genotypes. Sabrao J. Breeding and Genetics, 49: 270-279.

Cattivelli, L., F. Rizza, F. W. Badeck, E. Mazzucotelli, A. M. Mastrangelo, E. Francia, C. Maré, A. Tondelli and A. M. Stanca (2008). Drought tolerance improvement in crop plants: An integrated view from breeding to genomics. Field Crops Res., 105:1-14.

De Lima Pereira, J. W., M. B. Albuquerque, P. A. Melo Filho, R. J. M. C. Nogueira, L. M. de Lima and R. C. Santos (2016). Assessment of drought tolerance of peanut cultivars based on physiological and yield traits in a semiarid environment. Agric. Water Management, 166: 70-76.

El-Areny, I. M. (2015). Efficiency of some selection methods improve productivity and quality in peanut (Arachis hypogea L.). Ph.D. (Agri.) Thesis, Suez Canal Univ. Agric. Fac., Agron. Dep.

FAO (2008). FAOSTAT Agricultural Statistical Data Base.

Fonceka, D., H. A. Tossim, R. Rivallan, H. Vignes, E. Lacut, F. De Bellis, I. Faye, O. Ndoye, S. C. Leal-Bertioli, J. F., Valls and D. J. Bertioli (2012). Construction of chromosome segment substitution lines in peanut (Arachis hypogaea L.) using a wild synthetic and QTL mapping for plant morphology. PLoS One, 7(11).

FAO (2020). FAOSTAT Agricultural Statistical Data Base.

Geigenberger, P., R. Reimholz, M. Geiger, L. Merlo, V. Canale and M. Stitt (1997). Regulation of sucrose and starch metabolism in potato tubers in response to short- term water deficit. Planta, 201: 502-518.

Gowda, M. V. C., R. Narasimhulu and P. V. Kenchanagoudar (2012). Study of genetic variability and correlations in selected peanut genotypes. Inter. J. Appl. Biol. Pharma. Technol., 3(1): 355-358.

Hamidou, F., O. Halilou and V. Vadez (2012). Assessment of peanut under combined heat and drought stress. J. Agronomy and Crop Sci., 199(1): 1-11.

Hanson, CH, HR Robinson and RS Comstock (1956). Biometrical studies of yield in segregating population of Korean lespedeza. Agron. J., 48: 268-272.

Jeyaramraja, P. R. and F. Woldesenbet (2014). Characterization of yield components in certain peanut (Arachis hypogaea 1.) Varieties of Ethiopia J. of Exper. Biology and Agric. Sciences, 2: 592-596.

Jibrin, M. S. and S. H. Habu. (2016). Phenotypic and genotypic variance and heritability estimates for oil content and other agronomic traits in peanut (Arachis hypogea L.). International Journal of Scientific Research and Engineering Studies (IJSRES), 3(3): March 2016 ISSN: $2349-8862$

Johnson, H. W., H. F. Robinson and R. E. Comstock (1955). Estimates of genetic and environmental variability in soybean. Agron. J., 47: 413-418.

Luis, J. M., P. Ozias-Akins, C. C. Holbrook, R. C. Kemerait Jr., J. L. Snider and V. Liakos (2016). Phenotyping peanut genotypes for drought tolerance. Peanut Science, 43(1): 3648.

Maria Balota (2012). Effects of drought and heat on peanut (Arachis hypogea L.) production. Virginia Cooperative Extension,1-2.

Meghala, G. Devi, M. Shanthi Priya, M. Reddi Sekhar and P. Latha (2019). Variability studies for yield, yield attributes, water use efficiency and quality traits in peanut (Arachis hypogaea L.). Ind. J. Pure App. Biosci., 7(5): 393-398.

Menpadi, H. R. P. Patil, I. P. Manjugouda and D. G. Satihal (2015). Influence of stress mitigating compounds on quality parameters of peanut under moisture stress. Advances in Life Sciences, 5(6): 2451-2453. Print: ISSN 22783849.

Nassar, S. M. A., A. M. A. Al-Kady and Z. I. El-Saka (2018). Effect of drought stress on yield and yield components of 20 peanut genotypes grown under newly reclaimed soil. Egypt. J. Agro., 40(1): 45-58.

Paknejad, F., V. Bayat, M. R. Ardakani and S. Vazan (2012). Effect of methanol foliar application on seed yield and it's quality of soybean (Glycine max 1.) under water deficit conditions. AnnalsBio. Res., 3(5): 2108-2117.

Pereira, J. W. D. L., P. D. A. Melo Filho, M. B. Albuquerque, R. J. M. C. Nogueira and R. C. Santos (2012). Mudanças bioquímicas em genótipos de amendoimsubmetidos a déficit hídrico moderado. Revista Ciência Agronômica, Fortaleza, 43(4): 766-773.

Pereiral, J. W., E. C. A. da Silva, L. N. Da Luz, R. J. M. C. Nogueira, P. A. M. Filho, L. M. Lima and R. C. Santos (2015). Cluster analysis to select peanut drought tolerance lines. Asian J. Crop Sci. (AJCS), 9(11): 1095-1105. 
Pimratch, S., S. Jogloy, N. Vorasoot, B. Toomsan, T. Kesmala, A. Patanothai and C. C. Holbrook (2010). Effects of drought on characters related to nitrogen fixation in peanut. Asian J. Plant Sci., 9: 402-413

Ratnakumar, P. and V. Vadez (2011). Peanut (Arachis hypogea) genotypes tolerant to intermittent drought maintain a high harvest index and have small leaf canopy under stress. Functional Plant Biology, 38(12): 1016-1023.

Reshma, A. (2014). Studies on growth, drought tolerance and yield of peanut genotypes (pre release and release) for early kharif situation. Thesis Acharya NG Agricultural University.

Roy, A., M. Lal Ahmed, Y. Amaravathi, K. Viswanath, J. Dayal Prasad Babu and B. Sreekanth (2018). Genetic variability, heritability and genetic advance of yield and yield attributes in peanut (Arachis hypogea L.). The Andhra Agric. J., 65(1): 88-91.

Shrief Saied A., Ashraf A. Abd El-Mohsen, Hashim M. Abdel-Lattif, Mohamed El Soda, H. S. Zein and Mahmoud M. Mabrouk (2020). Peanut improvement: drought stress and water use efficiency of some peanut genotypes grown under newly reclaimed soil. Plant Archives, 20(supp. 2): 1527-1536.

Savita, S. K., P. V. Kenchanagoudar and H. L. Nadaf (2014). Genetic variability for drought tolerance in advanced breeding lines of peanut (Arachis hypogaea L.). Karnataka J Agric. Sci., 27(2): 116-120.

Shankar, M., B. N. Harish Babu, R. Gobu and Sheshaiah (2019a). Studies on genetic variability, heritability and genetic advance in peanut (Arachis hypogaea L.) genotypes under normal and osmotic Stress in In vitro Condition. Int. J. Curr. Microbiol. App. Sci., 8(5): 473-483.

Shankar, M., B. N. Harish Babu and R. Gobu Sheshaiah (2019b). Studies on genetic variability, heritability and genetic advance in peanut (Arachis hypogea L.) genotypes under normal and moister stress condition in vegetative stage Journal of Pharmacognosy and Phytochemistry, 8(3): 4271-4277.

Shinde, B. M., A. S. Limaye, G. B. Deore and S. L. Laware (2010). Physiological responses of peanut (Arachis hypogaea L.) varieties to drought stress. Asian J. Exper. Bio. Sci., SCI.SPL: 65-68.

Shoba, D., N. Manivannan and P. Vindhiyavarman (2012). Correlation and path coefficient analysis in Peanut (Arachis hypogea L.). Madras Agric. J., 99(1-3): 18-20.

Songsri, P., S. Jogloy, N. Vorasoot, C. Akkasaeng, A. Patanothai and C. C. Holbrook (2008). Root distribution of drought resistant peanut genotypes in response to drought. J. Agron. Crop Sci., 194(2): 92-103.

Steel, R. G. D. and J. H. Torrie (1984). Principles and procedures of statistics. A biometric approach. 2nd ed. McGraw Hill Book Co., New York, USA.

Thakur, S. B., S. K. Ghimire, N. K. Chaudhary, S. M. Shrestha and B. Mishra (2013). Determination of relationship and path co-efficient between pod yield and yield component traits of peanut cultivars. Nepal J. Sci. Tech., 14(2): 1-8.

Thombare, A. D. (2017). Physiological approaches for drought mitigation in groundnut (Arachis hypogea L.) crop. Thesis submitted to the Dr. Balasaheb Sawant Konkan Krishi Vidyapeeth, Dapoli. (Agricultural University). Dist. Ratnagiri (Maharashtra State), India.

Vaghasia, P. M., K. V. Jadhav, L. L. Jivani and V. H. Kachhadiya (2010). Impact of water stress at different growth phases of summer peanut (Arachis hypogea L.) on growth and yield. Res. Crops., 11(2): 693-696.

Zurweller, B. A., A. Xavierb, B. L. Tillmanc, J. R. Mahand, P. R. Paytond, N. Puppalab and D. L. Rowlanda (2018). Pod yield performance and stability of peanut genotypes under differing soil water and regional conditions. J. Crop Improvement. 


\section{التباين الوراثي للمحصول ومكوناته لبعض التراكيب الوراثية للفول السوداني تحث مستويات ري مختلفة}

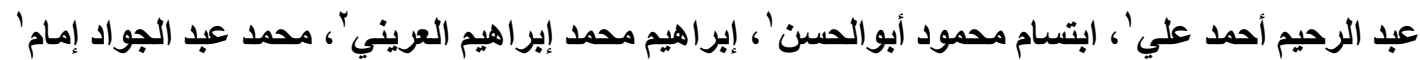

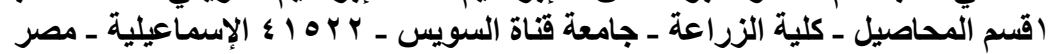

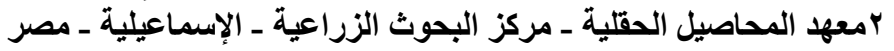

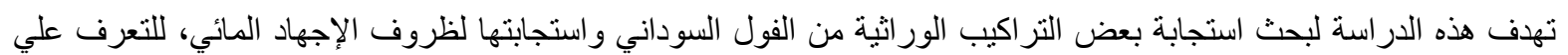

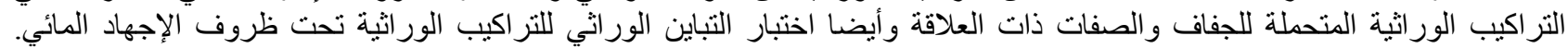

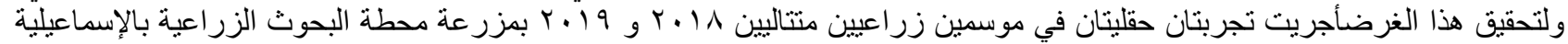

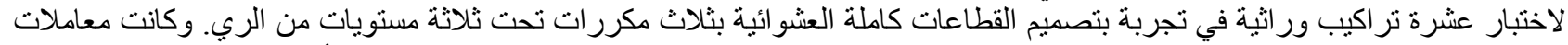

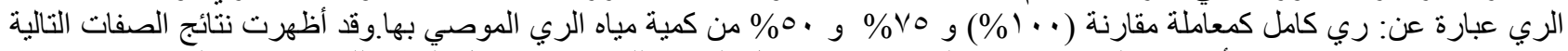

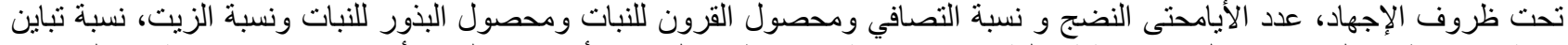

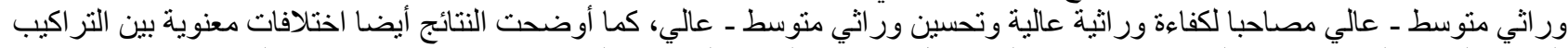

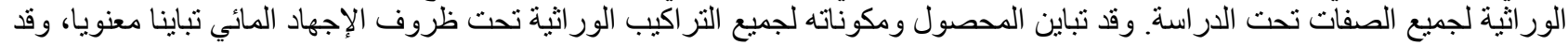

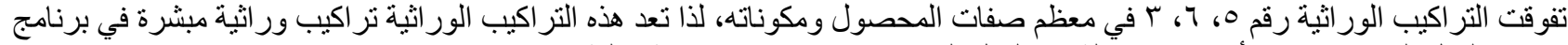
تحسين الفول السوداني لإنتاجأصناف متحملة من الفول النية السوداني تتميز بقدرة إنتاجية عالية. 